\title{
Vaktaalrubriek
}

\section{Veertig stappe in die saamstel van 'n vakwoordeboek}

\author{
M. Alberts \\ Terminologie-Afdeling, Nasionale Taaldiens, Departement van Kuns, Kultuur, Wetenskap en Tegnologie, Pretoria
}

\section{INLEIDING}

Vakkundiges ondervind soms die behoefte om hul kennis en die inligting oor hul vakgebied sistematies in die vorm van 'n vakwoordebock te dokumenteer. Hierdie artikel het ten doel om aan lesers insig te gee in die proses van die skep van 'n vakwoordeboek en om ook hulp te verleen aan vakkundiges wat moontlik self by die opstel van 'n vakwoordeboek betrokke is.

\section{BEPLANNING}

1 Doen ' $n$ behoeftebepalingsondersoek om te bepaal of daar werklik 'n behoefte aan die beplande vakwoordeboek in die vakgebied bestaan. Die saamstel van 'n vakwoordeboek is 'n baie langsame proses wat baie geduld en toewyding verg - ' $n$ mens kan nie met so 'n proses begin sonder ' $n$ wetenskaplike ondersoek nie.

2 Bepaal wie die teikengebruikers gaan wees. Die gebruikers bepaal grootliks die soort en omvang van die inligting wat in 'n vakwoordeboek aangebied word.

3 Bepaal met inagneming van die teikengebruikers die tipologie van die beoogde vakwoordeboek. Die tipologie moet die behoeftes van die teikengebruikers die beste dien. Besluite moet dus geneem word oor een-, twee- of meertaligheid. ' $n$ Eentalige vakwoordeboek sal bv. verklarend wees en meertalige vakwoordeboeke kan bloot vertalend of vertalend en verklarend wees. Daar moet ook besluit word oor die opneem van ensiklopediese inligting.

4 Bepaal wat die brontaal en doeltaal of doeltale gaan wees.

5 Baken die vakgebied af deur te bepaal watter terreine wel in die vakwoordeboek opgeneem behoort te word.

6 Bepaal wat die makrostruktuur (omvang) van die vakwoordeboek gaan wees.

7 Bepaal wat die mikrostruktuur (inligtingsvelde) van die vakwoordeboek gaan wees.

8 Kies ' $n$ vakkomitee wat verteenwoordigend is van die terreine (subvakgebiede) wat in die vakwoordeboek aan bod gaan kom.

9 Die vakkomitee moet nie net verteenwoordigend wees van die terreine (subvakgebiede) wat gedek gaan word nie. Die verskillende vlakke van onderrig moet verteenwoordig wees. As die vakgebied op universiteite of technikons, onderwyskolleges, skole aangebied word, is dit van belang dat hierdie belangegroepe ook betrek word (hulle is immers ook eindgebruikers/teikengebruikers). Dit sal verseker dat die vakwoordeboek deur die hele gebruikersgemeenskap aanvaar word. Dit sou ook die verkope van die vakwoordeboek positief stimuleer - veral as die vakwoordeboek dalk ook voorgeskryf kan word en indien die inhoud daarvan sodanig saamgestel word dat dit ' $n$ onontbeerlike instrument word in die leerproses van skoliere/studente.

10 Kies 'n voorsitter uit die geledere van die vakkomitee. Die voorsitter moet in alle opsigte 'n leier wees - 'n vakkenner sowel as 'n mensekenner (en veral 'n diplomaat), want redaksionele vergaderings kan heftige redenasies ontlok. 'n Mens moet in gedagte hou dat al die lede wat in die vakkomitee dien, gekies is vanweë sy/haar besondere vakkennis. Die individuele lede is dus ook leiers en daarom moet die voorsitter met die uiterste sorg gekies word. Die voorsitter moet ook iemand met sterk dryfkrag wees wat andere kan inspireer om deurlopend hul bes te doen.

11 Stel iemand aan as notulehouer - verkieslik 'n persoon wat ook as projekkoördineerder kan optree. Dit moet ' $n$ persoon wees wat logies kan dink, baie sistematies kan werk en verantwoordelik optree, want dié persoon gaan die hardste van almal werk! As daar 'n terminoloog/terminograaf beskikbaar is, sal dié persoon uiteraard vir die vakkomitee as notulehouer/ projekkoördineerder optree.

12 Werk 'n tydskedule uit in samehang met die beskikbare persone en frekwensie van vergaderings.

13 Identifiseer en bekom resente en relevante dokumentasie en naslaanwerke oor die verskillende subterreine: bv. handboeke, artikels in vaktydskrifte, opleidingsmateriaal, eksamenvraestelle....

14 Bepaal 'n werkswyse - m.a.w. wie gaan wat doen om die terminologiese data uit die geidentifiseerde bronne te ontsluit.

15 Bepaal die verskillende inligtingsvelde: brontaal, doeltaal/tale, woordsoort (nomen, verbum, adjektief), verklaring/definisie, verbandswoord, voorbeeldsin, navorsingsnota, grafika, simbool, afkorting, bibliografiese besonderhede.

16 Bepaal dan die woordeboek se stylgids - d.w.s. neem beleidsbesluite oor die inligtingsvelde en presies hoe die data in die inligtingsvelde aangebied moet word. Onthou bv. dat kollokasies en vaste uitdrukkings dikwels in die Geesteswetenskappe baie prominent voorkom en bepaalde besluite in dié verband is noodsaaklik. 'n Vakwoordeboek se stylgids kan aangepas word namante die projek vorder. Die konvensies en spesifieke verskynsels binne vakgebiede het ook 'n bepalende invloed op die stylgids. Die notulehouer moet alle stylgidsbesluite getrou notuleer, ' $n$ besluiteregister byhou (gereeld daarna terugverwys) en noulettend toesien dat sulke besluite konsekwent regdeur die woordeboekprojek se ontwikkeling toegepas word.

17 Kies dan 'n rekenaardatabasisprogram waarin die inligting gedokumenteer kan word en wat die tersaaklike inligtingsvelde kan hanteer

18 Onderhandel met 'n uitgewer. Uitgewers is dikwels nie bereid om ' $n$ vakwoordeboek van groot omvang te publiseer wat nie ' $n$ wye verbruikersmark het nie. 'n Universiteit se uitgewer is waarskynlik die mees aangewese. Onthou dat satellietlyste vir bepaalde teikengebruikers uit 'n omvattende databasis geabstraheer kan word.

\section{TERMINOGRAFIEPROSES}

19 As daar reeds 'n vakwoordeboek bestaan wat bygewerk of hersien moet word, moet die bron rekenaarmatig ingelees 
word. So 'n bestaande vakwoordeboek is van onskatbare waarde omdat dit 'n basis vorm vir die nuwe produk. Die bestaande vakwoordeboek moet deurgewerk word om te bepaal wat bruikbaar/verouderd/foutief is.

20 Die vakkundiges/terminoloë ekserpeer die tersaaklike nuwe bronne. Die bronne kan verdeel word om die data vinniger te versamel.

21 Ekserpeer die tersaaklike terme uit nuwe bronne deur hulle in die teks te onderstreep. Die persoon wat ekserpeer kan die terme direk in die databasis insleutel of kan 'n datatikster versoek om die terme wat onderstreep is, in te voer. Dit is egter makliker as die ekserpeerder dadelik die terme invoer sodat die brontaalinligting (bv. woordsoort, navorsingsnota, verklaring of verbandswoord, voorbeeldsin, bibliografiese besonderhede) direk ingesleutel kan word.

22 Indien die vakkundige/terminoloog die terme slegs onderstreep het, moet hulle nou deur 'n datatikster in die databasis ingevoer word.

23 Die vakkundige/terminoloog moet nou sorg dat die ekstra inligting wat as termtoeligting dien, ook bygevoeg word.

24 Verklaar die brontaalterme met behulp van resente en relevante vakwoordeboeke wat reeds op die terrein bestaan. Indien definisies nie in bestaande bronne beskikbaar is nie, moet die vakkundiges dit self saamstel met inagneming van sekere basiese terminografiese beginsels (waarmee die terminoloë kan help).

25 Proeflees die brontaalinligting deeglik om te verhoed dat spelfoute of toeligtingsfoute die omskakelingsproses bemoeilik.

26 Verskaf termekwivalente in die doeltaal. As terme geskep word, word dit gedoen in ooreenstemming met die besondere taal se spel- en skryfwyse.

27 Vertaal die verklaring/definisie in die doeltaal.

28 Skakel die teks om sodat die doeltaal nou brontaal word (as die brontaal bv. Engels was en die doeltaal Afrikaans, word Afrikaans nou die brontaal en Engels die doeltaal). Eers wanneer die teks omgeskakel is, kan die terminoloog werklik bepaal of die vertalings eenvormig gedoen is. Dit gebeur dikwels dat brontaalterme met verskillende doeltaalekwivalente vertaal word of dat sekere doeltaalekwivalente uit pas is met terminologiese patroonmatighede. Sulke terme moet dan met eindredigering reggemaak word. Wanneer'n mens na die omgeskakelde teks in druk kyk, sien jy inkonsekwenthede makliker raak.

\section{REDAKSIONELE VERGADERINGS}

29 Die verskillende lede van die vakkomitee moet gereeld byeenkom om die terme wat reeds van termekwivalente en ander termtoeligting voorsien is, te bespreek ten einde daardie terme dan as afgehandel te beskou.

30 'n Sekretaris moet deeglik notule hou van wat tydens hierdie vergaderings besluit word sodat die databasis dienooreenkomstig bygewerk kan word.

$31 \mathrm{Na}$ afloop van 'n redaksionele vergadering, bring die terminoloog ook die nodige wysigings op die databasis ann van terme wat reeds ingesleutel was, maar wat die vakkomitee tydens die jongste vergadering om bepaalde redes gewysig/ aangepas het.

32 Die wysigings word as bylaag by ' $n$ volgende redaksionele vergadering se agenda aangeheg sodat die vakkundige lede kan kontroleer of die notulehouer die wysigings korrek aangebring het.

33 Dié proses word met elke afsonderlike terrein (subvak- gebied) herhaal totdat die vakwoordeboek voltooi is

34 Die proses kan vinniger afgehandel word, indien die kenners op die verskillende terreine gelyktydig daaraan werk. Hulle kan dan die afgehandelde terme waarvoor hulle elkeen verantwoordelik is tydens die redaksionele vergaderings voorlê en die afgehandelde terminligting kan in die databasis ingesleutel word.

$35 \mathrm{Na}$ omskakeling is dit ook die werk van die vakkomitee (of van 'n kernkomitee aangewys uit die geledere van die vakkomitee) om al die probleme wat na aanleiding van die omskakeling aan die lig kom, sinvol op te los en vir woordeboekdoeleindes reg te stel. Alle onopgeloste terminologiese inkonsekwenthede moet aandag geniet. Met omskakeling en eindredigering sal terme wat bv. patroonmatig uit pas is, onnodige vertraging van die eindproduk tot gevolg hê.

\section{FINALE AFRONDING}

36 Die voorsitter van die redaksionele komitee is verantwoordelik vir die skryf van die voorwoord. Dit is dus van belang dat hy/sy deurlopend aantekeninge hou van die geskiedenis en verloop van die betrokke vakwoordeboek.

37 Die voorsitter en notulehouer kan die voorstukke van die vakwoordeboek saam voorberei. Die voorstukke is die gedeelte in ' $n$ woordeboek wat die redaksionele beleid uitspel. Daarin word

- vermeld wat die spesifieke nut van die vakwoordeboek vir welke teikengebruikers is;

- vermeld waarom die vakwoordeboek bepaalde terreine dek en ander uitlaat;

- vermeld watter probleme ondervind is tydens die saamstel van die vakwoordeboek;

- vermeld waarom 'n spesifieke tipologie gekies is;

- vermeld watter metodiek gevolg is;

- verantwoording gedoen oor die keuse van bron- en doeltaal/ -tale en gesê wat die spesifieke vakwoordeboek se bydrae is tot die algemene ontwikkeling van die besondere tale;

- probleemterme bespreek.

38 Dit is van die uiterste belang dat die redaksionele komitee hulself kan verantwoord en daarom is dit van belang dat alle besluite behoorlik genotuleer word.

39 Die agterstukke van die vakwoordeboek moet ook voorberei word. Daarin word o.a. 'n bibliografie verskaf van alle bronne, vakwoordeboeke en woordeboeke, instansies, individue, ens. wat geraadpleeg is. Indien die redaksionele komitee besluit om bylaes van watter aard ook al in te voeg, vorm dit ook deel van die agterstukke. Bylaes wat agterin bygevoeg word se inhoud moet funksioneel aanpas by die terminologiese inligting wat in die alfabetiese deel aangebied word en moet dus sodoende die publikasie se waarde as naslaanbron verhoog.

40 Dra sorg dat die vakwoordeboek behoorlik geproeflees is om te verseker dat daar geen foute voorkom nie. Die voordeel van 'n gerekenariseerde databasisprogram is dat as die data korrek ingevoer is, dit die moontlikheid van foute grootliks elimineer. Sodra die teks behoorlik finaal geredigeer is, kan 'n finale drukstuk aan die uitgewer gegee word vir vermeerdering en publikasie.

\section{NAVRAE:}

Dr. Mariëtta Alberts

Terminologie-A fdeling, Nasionale Taaldiens

Departement van Kuns, Kultuur, Wetenskap en Tegnologie

E-pos: M.Alberts@DACST5.pwv.gov.za; Tel.: (012)3378105

Faks.: (012) 3242119 ; Sel.: 0833069924 